\title{
Taboos: A curse to oral health: socio-cultural beliefs among adult population of Muradnagar, Ghaziabad- A cross-sectional study
}

\author{
Anubrata Barman ${ }^{1 *}$, Aastha Garg ${ }^{2}$, Ritu Gupta ${ }^{3}$, Ipseeta Menon ${ }^{4}$ \\ ${ }^{1,2}$ BDS Intern, ${ }^{3}$ Reader, ${ }^{4}$ Professor and Head, Dept. of Public Health Dentistry, I.T.S CDSR Muradnagar, Ghaziabad, Uttar Pradesh, India
}

\author{
*Corresponding Author: Anubrata Barman
}

Email: anubratabarman16@gmail.com

\begin{abstract}
Introduction: People have a strong belief in the myths and taboos related to oral health which has a huge effect in the prevention and treatment of oral diseases. Thus the objective of this study was to find the cultural beliefs and association between the taboos in dentistry and adult oral health behaviour in the population of Muradnagar, Ghaziabad.

Materials and Methods: Adult study subjects who visited the OPD above the age of 18 years were included. Demographic details like age, gender, occupation was recorded. A 11-item pre-tested questionnaire was interviewer administered to assess the cultural beliefs, taboos and myths regarding oral health.

Result: A total of 50 adults with a mean age of $39.56 \pm 16.41$ years were included in the study. Majority (84\%) of the respondent believed that teething causes fever. There was no significant correlation between the genders and the myths and taboos regarding oral health.Significantly higher unemployed $(50 \%)$ and daily-wage workers $(23.7 \%)$ believed that tooth cleaning causes sensitivity of teeth when compared to salaried $(10.5 \%)$ and businessman $(15.8 \%)$. $(\mathrm{p} \leq 0.05)$.

Conclusion: The present study depicted high prevalence of myths and taboos regarding oral health. It is common not only among the unemployed but also among elite and working class. If community is educated for proper prevention and cure, the myths relating dental concepts will vanish from the society and over all dental health status of the community will improve.
\end{abstract}

Keywords: Taboos, Myths, Cultural beliefs, Oral health.

\section{Introduction}

India is a very diverse country with different religion, culture and beliefs. It varies according to region and people staying in rural and urban areas. In India majority of population resides in rural areas, therefore people have their own beliefs and practices concerning health and disease, which equally affects oral diseases and treatments.

Culture is defined as a learned behaviour which is socially acquired. It is transferred from one group to another through learning process. ${ }^{1}$ All these customs, cultural morals, habits, beliefs, superstitions and taboos has a huge effect on people's mindset in both rural and urban areas, though due to little more awareness it is seen less in urban areas. And all this hugely affects the oral health of the general public.

Communities with inappropriate exposure to oral health care delivery systems are at higher risk of oral diseases, when socio-cultural determinants such as poor living conditions; low education; lack of traditions, beliefs, culture $\&$ myths related to oral health are more prevalent.

A taboo is a strong social prohibition relating to any area of human activity or social custom that is sacred and forbidden based on moral judgment and religious beliefs. ${ }^{1}$ Similarly, a myth is commonly a false belief, a misconception, or a fictitious or imaginary understanding of a thing or a person and has no relevance with reality.

Myths can be prevalent in a population due to a variety of reasons such as poor education, cultural beliefs, and social misconceptions. In general, myths are usually passed on from one generation to the next generation. Myths are deep seated in the society, so it is difficult to break the chain. It is important to know about these myths and misconceptions prevalent in the population as understanding them is essential to provide good care as well as health education to the people. ${ }^{2}$

Oral health is a critical but an overlooked component of overall health and well-being among children and adults. People believe in spiritual treatment and alternative forms of medicine, they prefer visiting a hakim (local traditional practitioner) over a doctor, or a roadside quake for any oral health problems rather than visiting a well qualified doctor.

Thus, aim of the study was to study the cultural beliefs about oral health in adults, to know the existing taboos and myths about dentistry among population, to assess the variation of these taboos and myths across various demographic aspects.

\section{Materials and Methods}

The present cross-sectional study was carried in the Out Patient department, I.T.S Centre for Dental Sciences and Research, Muradnagar, Ghaziabad from March to April 2019. Informed written consents were taken from participants. Ethical clearance was obtained from the Institutional Review Board.

A convenient sample of 50 adult study subjects who visited the OPD and at the camps above the age of 20years were included. Demographic details like age, gender, occupation was recorded. A11-item pre-test questionnaire was interviewer administered to assess the cultural beliefs, taboos and myths regarding oral health.

Data were analysed by the SPSSv 19 Statistical Package Software for the Social Sciences (SPSS Inc., Chicago, IL, USA). Descriptive statistics such as mean, median, standard deviation and percentage was used. 
Comparison of frequencies was done using Chi-Square test. Any p-value less than 0.05 were considered significant.

\section{Results}

Demographic details

The study participant aged from 20-60 years with a mean age of $39.56 \pm 16.41$ years.

Of the 50 study participants, 24(48.0\%) were males and $26(52.0 \%)$ were females.

Majority (38\%) were unemployed, $22 \%$ each were salaried and businessman respectively and $18 \%$ were daily wage workers. (Table 1)
Table 1: Demographic details

\begin{tabular}{|l|c|c|}
\hline Age Group (in years) & Number & Percentage \\
\hline $20-30$ & 18 & $36 \%$ \\
\hline $31-40$ & 17 & $34 \%$ \\
\hline $41-50$ & 5 & $10 \%$ \\
\hline $51-60$ & 10 & $20 \%$ \\
\hline Gender & & \\
\hline Male & 24 & $48 \%$ \\
\hline Female & 26 & $52 \%$ \\
\hline Occupation & & \\
\hline Unemployed & 19 & $38 \%$ \\
\hline Daily wage workers & 9 & $18 \%$ \\
\hline Salaried & 11 & $22 \%$ \\
\hline Business & 11 & $22 \%$ \\
\hline
\end{tabular}

$76 \%$ of the respondents believed, that tooth cleaning causes sensitivity of teeth, majority $(84 \%)$ of the study participants believed that teething causes fever, only $6 \%$ had a belief that worms of tooth decay can be removed from ears. (Table 2)

Table 2: Questions for assessing cultural beliefs and taboos in dentistry among adult population

\begin{tabular}{|c|c|c|}
\hline Questions & $\begin{array}{l}\text { Response } \\
\text { Yes }(\%)\end{array}$ & $\begin{array}{l}\text { Response } \\
\text { No }(\%)\end{array}$ \\
\hline Q1-Do you think extraction of upper teeth affects eyesight? & $33(66.0)$ & $17(34.0)$ \\
\hline Q2- Do you think cleaning of teeth with fingers is better than brushing? & $23(46.0)$ & $27(54.0)$ \\
\hline Q3- Do you believe use of clove, supari ease tooth pain? & $16(32.0)$ & $34(68.0)$ \\
\hline Q4- Do you think it's better not to brush in case of gingival bleeding? & $27(54.0)$ & $23(46.0)$ \\
\hline Q5- Do you think worms of tooth decay can be removed from ears? & $03(6.0)$ & $47(94.0)$ \\
\hline Q6- Do you believe that teething causes fever? & $42(84.0)$ & $08(16.0)$ \\
\hline Q7- Do you believe that tooth cleaning (scaling) causes tooth mobility? & $26(52.0)$ & $24(46.0)$ \\
\hline Q8- Do you believe that tooth cleaning causes sensitivity of teeth? & $38(76.0)$ & $12(4.0)$ \\
\hline $\begin{array}{l}\text { Q9- Do you think that there is no need to treat the dental problems in milk } \\
\text { teeth? }\end{array}$ & $25(50.0)$ & $25(50.0)$ \\
\hline $\begin{array}{l}\text { Q10- Do you think that orthodontic treatment should not be done at younger } \\
\text { age? }\end{array}$ & $27(54.0)$ & $23(46.0)$ \\
\hline Q11- Do you think RPDs are fixed prosthesis? & $31(62.0)$ & $19(38.0)$ \\
\hline
\end{tabular}

Comparison of responses between males and females showed no statically significant difference for all the questions (Table 3)

Table 3: Gender wise response of the questionnaire

\begin{tabular}{|c|c|c|c|c|c|}
\hline \multirow[t]{2}{*}{ Questions } & \multirow[t]{2}{*}{ Responses } & \multirow{2}{*}{$\begin{array}{l}\text { Males } \\
\mathbf{N}(\%)\end{array}$} & \multirow{2}{*}{$\begin{array}{c}\text { Females } \\
\mathbf{N}(\%)\end{array}$} & \multicolumn{2}{|c|}{ Chi-Square } \\
\hline & & & & p-value & significance \\
\hline \multirow{2}{*}{$\begin{array}{l}\text { Q1 Do you think extraction of upper teeth affects } \\
\text { eyesight? }\end{array}$} & Yes & $14(42.4)$ & $19(57.6)$ & \multirow[t]{2}{*}{0.059} & \multirow[t]{2}{*}{ NS } \\
\hline & No & $12(70.6)$ & $5(29.4)$ & & \\
\hline \multirow{2}{*}{$\begin{array}{l}\text { Q2 Do you think cleaning of teeth with fingers is } \\
\text { better than brushing? }\end{array}$} & Yes & $13(56.5)$ & $10(43.5)$ & \multirow[t]{2}{*}{0.555} & \multirow[t]{2}{*}{ NS } \\
\hline & No & $13(48.1)$ & $14(51.9)$ & & \\
\hline \multirow{2}{*}{$\begin{array}{l}\text { Q3 Do you believe use of clove, supari ease tooth } \\
\text { pain? }\end{array}$} & Yes & $8(50)$ & $8(50)$ & \multirow[t]{2}{*}{0.846} & \multirow[t]{2}{*}{ NS } \\
\hline & No & $18(52.9)$ & $16(47.1)$ & & \\
\hline \multirow{2}{*}{$\begin{array}{l}\text { Q4 Do you think it's better not to brush in case of } \\
\text { gingival bleeding? }\end{array}$} & Yes & $15(55.6)$ & $12(44.4)$ & \multirow[t]{2}{*}{0.586} & \multirow[t]{2}{*}{ NS } \\
\hline & No & $11(47.8)$ & $12(52.2)$ & & \\
\hline \multirow{2}{*}{$\begin{array}{l}\text { Q5 Do you think worms of tooth decay can be } \\
\text { removed from ears? }\end{array}$} & Yes & $2(66.7)$ & $1(33.3)$ & \multirow[t]{2}{*}{0.600} & \multirow[t]{2}{*}{ NS } \\
\hline & No & $24(51.1)$ & $23(48.9)$ & & \\
\hline \multirow[t]{2}{*}{ Q6 Do you believe that teething causes fever? } & Yes & $22(52 . .4)$ & 20(47.6) & \multirow[t]{2}{*}{0.902} & \multirow[t]{2}{*}{ NS } \\
\hline & No & $4(50.0)$ & $4(50.0)$ & & \\
\hline \multirow{2}{*}{$\begin{array}{l}\text { Q7 Do you believe that tooth cleaning (scaling) } \\
\text { causes tooth mobility? }\end{array}$} & Yes & $12(46.2)$ & $14(53.8)$ & \multirow[t]{2}{*}{0.389} & \multirow[t]{2}{*}{ NS } \\
\hline & No & $14(58.3)$ & $10(41.7)$ & & \\
\hline \multirow{2}{*}{$\begin{array}{l}\text { Q8 Do you believe that tooth cleaning causes } \\
\text { sensitivity of teeth? }\end{array}$} & Yes & $19(50)$ & $19(50)$ & \multirow[t]{2}{*}{0.614} & \multirow[t]{2}{*}{ NS } \\
\hline & No & $7(58.3)$ & $5(41.7)$ & & \\
\hline \multirow{2}{*}{$\begin{array}{l}\text { Q9 Do you think that there is no need to treat the } \\
\text { dental problems in milk teeth? }\end{array}$} & Yes & $12(48.0)$ & $13(52)$ & \multirow[t]{2}{*}{0.571} & \multirow[t]{2}{*}{ NS } \\
\hline & No & $14(56)$ & $11(44)$ & & \\
\hline
\end{tabular}




\begin{tabular}{|l|l|c|c|c|c|}
\hline \multirow{2}{*}{$\begin{array}{l}\text { Q10 Do you think that orthodontic treatment should } \\
\text { not be done at younger age? }\end{array}$} & Yes & $13(48.1)$ & $14(51.9)$ & 0.555 & \multirow{2}{*}{ NS } \\
\cline { 1 - 4 } & No & $13(56.5)$ & $10(43.5)$ & & \\
\hline
\end{tabular}

Significantly higher unemployed (50\%) and daily-wage workers $(23.7 \%)$ believed that tooth cleaning causes sensitivity of teeth when compared to salaried (10.5\%) and businessman (15.8\%).

Also significantly higher percentages of unemployed and daily-wage workers thought RPDs are fixed prosthesis when compared to respondents who were salaried and the ones involved in business. $(\mathrm{p} \leq 0.05)$ no significant difference in responses to other questions based on occupation was observed $(\mathrm{p} \geq 0.05)$ (Table 4)

Table 4: occupation wise responses of the questionnaire

\begin{tabular}{|c|c|c|c|c|c|c|c|}
\hline \multirow[t]{2}{*}{ Questions } & \multirow[t]{2}{*}{ Responses } & \multirow{2}{*}{$\begin{array}{l}\text { Unemployed } \\
\mathbf{N}(\%)\end{array}$} & \multirow{2}{*}{$\begin{array}{l}\text { Daily Wage } \\
\mathbf{N}(\%)\end{array}$} & \multirow{2}{*}{$\begin{array}{c}\text { Salaried } \\
\mathrm{N}(\%)\end{array}$} & \multirow{2}{*}{$\begin{array}{c}\text { Business } \\
\mathrm{N}(\%)\end{array}$} & \multicolumn{2}{|c|}{ Fisher Freeman Halton } \\
\hline & & & & & & P-Value & Significance \\
\hline \multirow{2}{*}{$\begin{array}{l}\text { Q1 Do you think extraction of upper } \\
\text { teeth affects eyesight? }\end{array}$} & Yes & $14(42.4)$ & $6(18.2)$ & $6(18.2)$ & $7(21.2)$ & \multirow{2}{*}{0.784} & \multirow[t]{2}{*}{ NS } \\
\hline & No & $5(29.4)$ & $3(17.6)$ & $5(29.4)$ & $4(23.5)$ & & \\
\hline \multirow{2}{*}{$\begin{array}{l}\text { Q2 Do you think cleaning of teeth } \\
\text { with fingers is better than brushing? }\end{array}$} & Yes & $10(43.5)$ & $5(21.7)$ & $3(13)$ & $5(21.7)$ & \multirow[t]{2}{*}{0.528} & \multirow[t]{2}{*}{ NS } \\
\hline & No & $9(33.3)$ & $4(14.8)$ & $8(29.6)$ & $6(22.2$ & & \\
\hline \multirow{2}{*}{$\begin{array}{l}\text { Q3 Do you believe use of clove, supari } \\
\text { ease tooth pain? }\end{array}$} & Yes & $7(43.8)$ & $2(12.5)$ & $3(18.3)$ & $4(25)$ & \multirow[t]{2}{*}{0.847} & \multirow[t]{2}{*}{ NS } \\
\hline & No & $12(35.3)$ & $7(20.6)$ & $8(23.5)$ & 7(63.6) & & \\
\hline \multirow{2}{*}{$\begin{array}{l}\text { Q4 Do you think it's better not to } \\
\text { brush in case of gingival bleeding? }\end{array}$} & Yes & $8(29.6)$ & $7(25.9)$ & $6(22.2)$ & $6(22.2)$ & \multirow[t]{2}{*}{0.372} & \multirow[t]{2}{*}{ NS } \\
\hline & No & $11(47.7)$ & $2(8.7)$ & $5(21.7)$ & $5(21.7)$ & & \\
\hline \multirow{2}{*}{$\begin{array}{l}\text { Q5 Do you think worms of tooth } \\
\text { decay can be removed from ears? }\end{array}$} & Yes & $1(33.3)$ & $1(33.3)$ & $1(33.3)$ & $0(0.00)$ & \multirow[t]{2}{*}{0.724} & \multirow[t]{2}{*}{ NS } \\
\hline & No & $18(38.3)$ & $8(17.0)$ & $10(21.3)$ & $11(23.4)$ & & \\
\hline \multirow{2}{*}{$\begin{array}{l}\text { Q6 Do you believe that teething causes } \\
\text { fever? }\end{array}$} & Yes & $17(40.5)$ & $9(21.4)$ & $7(16.7)$ & $9(21.4)$ & \multirow[t]{2}{*}{0.164} & \multirow[t]{2}{*}{ NS } \\
\hline & No & $2((25)$ & $0(0)$ & $4(50)$ & $2(25)$ & & \\
\hline \multirow{2}{*}{$\begin{array}{l}\text { Q7 Do you believe that tooth cleaning } \\
\text { (scaling) causes tooth mobility? }\end{array}$} & Yes & $13(50)$ & $6(23.1)$ & $3(11.5)$ & $4(15.4)$ & \multirow[t]{2}{*}{0.086} & \multirow[t]{2}{*}{ NS } \\
\hline & No & $6(25)$ & $3(12.5)$ & $8(33.3)$ & $7(29.2)$ & & \\
\hline \multirow{2}{*}{$\begin{array}{l}\text { Q8 Do you believe that tooth cleaning } \\
\text { causes sensitivity of teeth? }\end{array}$} & Yes & $19(50)$ & $9(23.7)$ & $4(10.5)$ & $6(15.8)$ & \multirow[t]{2}{*}{0.00} & \multirow[t]{2}{*}{ HS } \\
\hline & No & $0(0)$ & $0(0)$ & $7(58.3)$ & $5(41.7)$ & & \\
\hline \multirow{2}{*}{$\begin{array}{l}\text { Q9 Do you think that there is no need } \\
\text { to treat the dental problems in milk } \\
\text { teeth? }\end{array}$} & Yes & $9(36)$ & $5(20)$ & $4(16)$ & $7(28)$ & \multirow[t]{2}{*}{0.615} & NS \\
\hline & No & $10(40)$ & $4(16)$ & $7(28)$ & $4(16)$ & & \\
\hline Q10 Do you think that orthodontic & Yes & $11(40.7)$ & $6(22.2)$ & $6(22.2)$ & $4(14.8)$ & 0.557 & NS \\
\hline $\begin{array}{l}\text { treatment should not be done at } \\
\text { younger age? }\end{array}$ & No & $8(34.8)$ & $3(13)$ & $5(21.7)$ & $7(30.4)$ & & \\
\hline Q11 Do you think RPDs are fixed & Yes & $13(41.9)$ & $9(29)$ & $5(16.1)$ & $4(12.9)$ & 0.017 & $\mathrm{~S}$ \\
\hline prosthesis? & No & $6(31.6)$ & $0(0)$ & $6(31.6)$ & $7(36.8)$ & & \\
\hline
\end{tabular}

\section{Discussion}

This study was performed to investigate the existence of myths and taboos, to assess the variation of these myths across various demographic aspects and to impart education to the people regarding abolishing the myth as that will be a hindrance towards a healthy life in patients visiting Dental Hospital.India, a developing country faces many challenges infulfilling oral health needs of the population. And in addition to this, there is a major effect of myths and taboos on health seeking behaviour in the Indian population.

In the present study it was found that $66 \%$ of respondent believe that extraction of upper teeth affects the eyesight which is more than that of study done by Khan SA et $\mathrm{al}^{5}(47 \%)$, Sharma $\mathrm{R}$ et $\mathrm{al}^{3}(64 \%)$, Kochhar $\mathrm{S}$ et $\mathrm{al}^{7}$ (49.6\%), Pandya $\mathrm{P}$ et $\mathrm{al}^{9}(42.7 \%)$, Raina SA et $\mathrm{al}^{8}(52.4 \%)$,

Rai $A$ et $\mathrm{al}^{6}(19.1 \%)$. For example, extractions performed on older patients, leading to weakening of eye sight due to its vicinity in maxilla, are mere coincidental, but still remain a taboo, hence people relate to this. About $46 \%$ of the subjects still use finger instead of toothbrush as a cleaning aid, which is slightly less than the study done by
Kochhar S et $\mathrm{al}^{7}(46.6 \%)$ and more than the study done by Rai A et al (11.4\%), ${ }^{6}$ which may be due to poor education. Many people in the countryside use twigs of neem tree as a tooth brush, some use ashes, salt rice husks, tobacco and some charcoal, ${ }^{10}$ therefore they believe using finger is better than using brush and 54\% believes that brush should be used as a cleaning aid rather than finger \& these could be the educated ones and those who have come in contact with urban life use tooth brushes. In this modern progressing times also still $32 \%$ of the participants still depend on the cultural beliefs and taboos in curing their dental health problems and believes that use of clove, supari ease tooth pain which is lower than the study done by Sharma $\mathrm{R} \mathrm{et} \mathrm{al}^{3}$ (54\%), Kochhar S et $\mathrm{al}^{7}(57.8 \%)$, Rai A et $\mathrm{al}^{6}(49.4 \%)$. It may be attributed to the fact that the products like clove are easily available and relieve pain quickly and are cost effective and available as a household material that are mostly used in developing countries like India. In gum bleeding 54\% participants believed that it was better not to brush, which was more than the study done by Nagarajappa R. et al. ${ }^{4}(16.5 \%)$ and less than the study done by Kochhar S 
et $\mathrm{al}^{7}(58.4 \%)$ and less than the study done by Rai $\mathrm{A}$ et $\mathrm{al}^{6}$ (73.4\%), since they believe that it may aggravate the condition. Because of the cultural beliefs $84 \%$ of the participants still believe that teething causes fever in a child, which is more than the study done by Rai A et $\mathrm{al}^{6}(50.9 \%)$. While eruption of teeth can slightly raise the child's body temperature but if body temperature is above the normal range i.e $36-37^{\circ} \mathrm{C}$, then it is a fever and which is because of some other problem and not because teething.

In this study $52 \%$ participant believes that cleaning of teeth through scaling cause mobility in teeth, which is lower than the study done by Sharma $\mathrm{R}$ et $\mathrm{al}^{3}(59.3 \%)$, Kochhar $\mathrm{S}$ et $\mathrm{al}^{7}(65.3 \%)$ and more than the study done by Raina SA et $\mathrm{al}^{8}(48 \%)$, Pandya $\mathrm{P}$ et $\mathrm{al}^{9}(46.7 \%)$. If poor oral hygiene is there then calculus deposits are obvious and teeth become periodontally weak which leads on to mobility, recession (periodontitis) but because heavy calculus deposits tooth tend to remain stable for some time, because of this just after removing these calculus through scaling the tooth become mobile and patient believe that cleaning of teeth has caused this and held the dentist responsible. Also due to removal of calculus and exposed area lead on to sensitivity for few days but $76 \%$ participant believes it is just because of the scaling.

In this study $50 \%$ of the participants believed that there was no need to visit the dentist for treatment of milk teeth, until all the permanent teeth of child erupts which was lower than the study done by Kochhar S et al. ${ }^{7}$ (73.8\%), Khan SA et. al. (72.5\%), ${ }^{5}$ Sharma $\mathrm{R}$ et $\mathrm{al}^{3}(57.8 \%)$ and more than the study done by Pandya $\mathrm{P}$ et $\mathrm{al}^{9}(38 \%)$, Raina SA et $\mathrm{al}^{8}$ $(47.9 \%)$. They think that these teeth are going to shed, so treating them as wastage of money and time but people are getting aware regarding this therefore this positive response was there. And also 54\% think that orthodontic treatment if done at younger age can affect the child's brain, hence it shouldn't be done at younger age. Only $6 \%$ believed that worm of tooth decay can be removed from ear, which is lower than the study done by Rai A et $\mathrm{al}^{6}(14 \%)$, this is because in earlier times it was believed tooth decay is caused because of some worm and still it is believed in some rural areas but now people are more aware regarding this.

$62 \%$ participant believed that the removal denture is the fixed one for replacement of any teeth. This is just because of the quacks who practice wrong dentistry by just sticking the typhodonts and sometimes extracted tooth with some material and also sometimes fixes the typhodonts with the natural tooth in the mouth directly with self-cure acrylic.

\section{Conclusion}

The present study depicted high prevalence of myths and taboos regarding oral health. It is common not only among the unemployed but also among elite and working class. If community is educated for proper prevention and cure, the myths relating dental concepts will vanish from the society and over all dental health status of the community will improve.

\section{Recommendation}

Dental health education awareness campaign is needed to change the mindset of the community. A multi-sectoral approach is required to address this problem, educate the people and work on oral health promotions. Primary health care workers should be trained to provide oral health education to the community. Also, further longitudinal studies with larger sample size can be carried for better generalizability of the data.

\section{Source of funding}

None.

\section{Conflict of interest}

None.

\section{References}

1. Chu MP. Chinese cultural taboos that affect their language \& behavior choices. Asian Culture Hist 2009;1(2):122-39.

2. Priyanka S, Leelavathi L. Myths related to dentistry - An Overview. Drug Invention Today 2018;10(4):3508-11.

3. Sharma R, Mallaiah P, Margabandhu S, Umashankar GK, Verma S. Dental Myth, Fallacies and Misconceptions and its Association with Socio-Dental Impact Locus of Control Scale. Int J Prevent Public Health Sci 2015;1(2):14-20.

4. Nagarajappa R, Sahare P, Shukla N, Tuteja JS, Bhalla A. Knowledge, Attitude and Practices Regarding Oral Health among Out Patients at Rama Dental College, Kanpur. Rama Univ J Dent Sci 2015;2(1):8-14.

5. Khan SA, Dawani N, Bilal S. Perceptions and myths regarding oral health care amongst strata of low socio economic community in Karachi, Pakistan. J Pak Med Assoc 2012;62:1198-203.

6. Rai A, Menon I, Aruna DS, Singh A. Association between taboos in dentistry and oral health behavior among adult population of Ghaziabad. J Dent Specialities 2016;4(1):14-20.

7. Kochhar S, Singh K, Anandani C, Pani P, Kaur Bhullar RP, Bhullar A. Occurrence of Oral Health Beliefs and Misconceptions Among Indian Population. J Dent Health Oral Disord Ther 2014;1(5):00031.

8. Raina SA, Jain PS, Warhadpande MM. Myths and taboos in dentistry. Int J Res Med Sci 2017;5:1936-42.

9. Pandya P, Bhambal A, Bhambani G, Bansal V, Kothari S, Divya K. Social Myths and Dental Care: Taboo. Peoples J Sci Res 2016:9(2):42-6.

10. Vani G, Ganesh Babu M, Panchanatham N. Toothpaste products analysis of consumer behavior in Bangalore city. $J$ Economics Behavioral Stud 2010;1(1):27-39.

How to cite the article: Barman A, Garg A, Gupta R, Menon I. Taboos; A curse to oral health: socio-cultural beliefs among adult population of Muradnagar, GhaziabadA cross-sectional study. J Dent Specialities 2019;7(2):10710. 